\title{
Thisness and Everydayness in Children's Literature: The 'being-in-the-world proposed by the text'
}

\author{
Rosemary Johnston
}

$P$ owerful and profound creativity is largely unconscious and polysemic. Through understanding it is supplemented by consciousness and the multiplicity of its meanings is revealed....

(M. M. Bakhtin)

An examination of the philosophical concepts of thisness (haecceitas) and everydayness in relation to children's literature, particularly picture books, yields a critical aesthetic through which to explore and understand some of the characteristics of books written for children.

Haecceitas was conceived by Johannes Duns Scotus, one of the great thinkers of the Middle Ages, as a principle which celebrates the particularity of ordinary things. It specifies the extra-ordinary of the ordinary, the quality of distinction and individuation which exists within this thing to make it different, as subjectivity, in the essentialist view at least, is the different essence of self-hood. 'Extra-ordinary' here means not out of the ordinary but inside it, deeply, as someone who is deeply happy says they are 'extra happy' or as something which has the quality of being dry, deeply, is 'extra dry'. The particularity of thisness then is its density or high concentration or specific configuration of the elements which it already contains.

Contemporary emphases in artistic production and theory on the significance of 'ordinary' life have led to examinations of the concept of everydayness as a re-appreciation of everyday activities. In a discussion comparing 'heroic life' and 'everyday life', Featherstone writes:

Postmodernism has...been associated with the positive evaluation of local and popular cultures, the minor traditions and the 'otherness' excluded by the universalistic pretension of the modern. This suggests an increasing sensitivity to the more complex levels of unity, to the syncret ism, heterogeneity, and the common taken-for-granted 'seen but unnoticed' aspects of everyday life.

(Featherstone 1992, p.159)
It is obvious that the ideologies of author and illustrator will inevitably influence their depictions of what the everyday looks like. However, literature in general and picture books in particular (because of the amount of visual detail used to depict the 'seen but unnoticed' aspects of the everyday) may unwittingly disclose more deeply rooted societal ideologies, attitudes and cultural assumptions. Edward's First Day at School by Rosemary Wells is a late twentieth century moral tale; both text and illustrations overtly depict an everyday where fathers play an equal role in caring for children (the father dresses Edward, the mother feeds him his porridge, 'together they put him in the car'); where parents are supportive (both parents at school having discussions with the teacher); where children are allowed to be different ('not everyone is ready...'), and where teachers are wise. More covertly, it encodes an ideological shift in societal notions of power. The twentieth century construct of the individual-centred universe is at the heart of this text. There are only two double-page illustrations: the first is of Edward being driven by his parents to playschool and the second shows him being driven away from it. The first shows the car against an unpeopled backdrop of houses, and only the top half of Edward's face. The second shows the car decisively turned away from the group at the school gate and pointing in the opposite direction. The car here is more whole and therefore stronger-it is drawn three quarters on rather than side on (as in the earlier picture). In the thisness of this moment, Edward is also more whole, his eyes are less apprehensive and we see part of his mouth, which looks satisfied if not triumphant. The thrust of this second picture is a celebratory going away from the cluster at the gate that represents society. The individual, who doesn't want to paint, or slide, or conform, withdraws from the 'everybody' who cheerfully supports his right to do so.

This book constructs a story underframed by ideas of readiness and the 'right time'. Both thisness and everydayness are closely related to temporality-time. 
Thisness concentrates on the specialised extraordinary of a particular moment. Everydayness concerns a pattern of behaviour repeated over a cycle of time; temporality, both a markand a measure of it, is the essence of its definition. Rimmon-Kenan's discussion of time in terms of the characteristics of order, duration and frequency (1983, p.46) seem appropriate here, as everyday activities occur, by definition, in an order which is consecutive-that is, day after day; are of a duration that makes them significant enough to be part of a pattern, and occur with frequency - that is, every day. The world of the everyday - of going to school and going home, of getbing up in the morning and going to bed at nightrepresents the textual world of countless picture books. It is interesting to note that in many instances the everyday is juxtaposed against the 'heroic', with its concomitant 'danger, violence and... courting of risk' (Featherstone 1992, p.165). If we read the middle part of Sendak's Where the Wild Things Are as Max's fantasy, it is a classic example of this type of juxtaposition; it is also a powerful declaration of the imaginative potential inherent in the everyday, a common theme in children's literature: Alice in Wonderland (Carroll), Come Away from the Water, Shirley (Burningham), Drac and the Gremlin (Baillie and Tanner), to name a few examples.

Literature articulates thisnesses of time within its construction of an everyday time. Everyday time imposes, at each criss-cross of thisness, implicit parameters of mortality and of normal human 'lifetime'. Paul Ricoeur refers to 'the fictive expression of time ...the temporal aspect of this virtual experience of being-in-the-world proposed by the text' and to the 'temporalities that are more or less extended, offering in each instance a differing figure of recollection, of eternity in or out of time, and...of the secret relation between eternity and death' (Ricoeur 1985, pp.100-101). ${ }^{1}$ Ricoeur is discussing here the opening up of the world of the text to an "outside" that it projects beyond itself and offers to critical appropriation by a reader' (p.100). These three concepts - the world of the text, the world that the text allows us to glimpse as the 'landscape beyond' itself ('an imaginary world [on] the horizon' of fictive world), and the 'life-world of the reader', without which, says Ricoeur, 'the signification of the literary work is incomplete' (p.160)-become more complex when considered in relation to literature written for children. Here another element of 'time' enters the construction of the everyday-the time of adult writers, writing for and of a time that was once their experience but is no longer-writing in one sense backward, butgenerally of the present; writing from a place with a different 'perspective of a landscape beyond' (p.100) but trying to construct some of the thisness of that other place's remembered features. Childhood is an intrinsically forward-orientated condition; it emerges out of a no-time into an accumulation of moments of presentness which are consistently gearing for change and ultimate redundancy. The world proposed by children's book authors and illustrators is characterised by a temporal tension between their desire to recrea te a contextual implication or horizon ('figure of recollection') of elongated child-time (on the childhood side of child hood) and their frequent desire to suppress the perceived reality of an opposite conception of childtime as intensely short, finite and 'lost' (on the adult side of childhood). Fictively, the temporal tropes of mortality in children's books are commonly of growth, passing through rather than passing on; the 'death' that is implicit (in Ricoeur's sense) is not the usual concept of death but that of growing up. When children are allowed to age beyond childhood in fictive time, as is the case with Anne Shirley, with the March girls, perhaps with Sendak's Ida, in Outside Over There, there is an accompaniment of pervasive sadness and even grief. Anne, for example, reaches the 'nice and grown-uppish' (p.104) state she had dreamed about but finds that nothing there is quite the same: 'It's fun to be almost grown up in some ways, but it's not the kind of fun I expected' (Montgomery 1983, p.213). To Marilla, 'conscious of a queer sorrowful sense of loss', Anne's growth has been like a death: 'The child she had learnt to love had vanished somehow and here was this tall, 
serious-eyed girl of fifteen...in her place' (p.212); later she explains her tears by telling Anne, 'I just couldn't help thinking of the little girl you used to be' (p.230).

There is another temporal tension as well. Outside the text, adults may (and do) carry their childhood reading experiences with them, and treasure some books that they may revisit with a sort of wistful pleasure, but for some adult readers these books come to represent a time or world that, even as they remember it, is lost to them and constitutes an almost hypothetical state. So writers and illustrators create a time-space which they know will be only briefly inhabited and which will be quickly 'grown out of', no matter how much they may desire to keep the child in [them]selves', and no matter how much they may seek to retain the qualities of 'childness' (Hollindale 1997, p.61). This imposes both urgency and sometimes a sort of defensiveness. There is also the obvious constraint of length: children's books and especially picture books tend to be short; textual space is limited. This means that the author and illustrator must be extremely selective not only in subject matter but also in the words and images they choose to propose the everyday world of their text, and its imaginary horizon.

These tensions and constraints work together to make children's texts temporally compressed, highly concentrated and urgent; this compression, concentration and urgency make it a literature which is characterised by thisness.

Ricoeur's comments provide a basis to explore thisness in three ways: firstly, as part of narrative through the depiction of children experiencing moments of thisness in the fictive worlds of novels and picture books; secondly, as it is glimpsed by the child reader in singular moments within the world that the text proposes beyond itself; and thirdly, and most significantly, in life-world as child readers encounter it again and again as an artistic feature of picture books in particular, not as one single glimpse but as a continual experience.
Thisness as an artistic feature is related to Gerard Manley Hopkins' notion of inscape, the term he coined to describe the spiritual perception and subsequent revelation of the innate uniqueness of all things. It is also related to James Joyce's concept of the epiphany and the epiphanic moment:

First we recognise that the moment is one integral thing, then we recognise that it is an organised composite structure, a thing in fact: finally, when the relation of the parts is exquisite, when the parts are adjusted to the special point, we recognise that it is that thing which it is. Its soul, its whatness, leaps to us from the vestment of its appearance. The soul of the commonest object, the struct ure of which is so adjusted, seems to us radiant. The object achieves its epiphany. (Joyce, Stephen Hero 1944, p.213)

It is important to note that the things that most inspired Hopkins in their revelation of inscape and which triggered the moment of epiphany for Joyce's characters, were in fact ordinary objects of everyday life; these were suddenly infused with a mystical revelation not just of beauty but in some subtle way of the human experience (the 'universal'). In Stephen Hero Stephen points to the clock of the Ballast office and explains that even that item of Dublin's 'street furniture' is capable of epiphany. These epiphanies are part of the world of the text and of the characters' experiences; they are also epiphanic glimpses of the world projected beyond the text.

I need to quote at this point from Peter Hollindale, writing about what he calls 'a literature for youth' (Hollindale 1997, p.60):

We need to remember, always, that youth can be very long, extending into the early stages of adult life. And we need to remember that although it is long, and a continuum, it is also marked by significant moments, for which we can properly use the Joycean term 'epiphanies'. Such moments vary in their nature. Some... are encapsulations of total childhood, fusions of actual or desired experience in single, unforgettable events. Others are times and moments when we feel our lives on the turn-irreversible movements forward 
into ad ult life, achievements of independence, confidence and control, proofs of self-value and of value in the eyes of others. Epiphanies such as these can be public and social, or private and secret. They can be lastingly remembered and permanently strengthening, or (a hard category, this) devoid of further significance once the moment of immediate euphoria has passed. In childhood and youth we can understand them better if we find them authentically reflected in story, and they can image for us the unspoken goals and values of the culture we inhabit.

(Hollindale 1997, pp.119-120)

My focus here is to extrapolate the aesthetic of the epiphany into an understanding of picture books themselves as concrete artistic representations, thisnesses, of the moments that Hollindale identifies. Children's books, and again picture books in particular, are characterised by both verbal and visual 'epiphanic moments' in fictive world-moments that are 'a particular revelation of an inner reality of an experience, accompanied with great elation, as in a mystical experience' (Booth 1968, p.87). However, picture books, as part of their artistic form, also present to the life-world of the reader image after image of the dense, concentrated, urgent focus of such moments-images of thisness. Sometimes there is a symbiotic connection. In Owl Babies (Waddell and Benson 1992), the double-page picture of the mother owl returning to her owl babies is powerful in its depiction of thisness as both narrative-an epiphanic moment experienced by the babies-and artistic structure. The simple words 'AND SHE CAME', printed in upper case, are amplified and made resonant by their dramatic presentation. However, the moment is further enhanced by the subsequent projection to child readers of the world beyond the text. The babies' subjective focalisation of their mother's coming and the largeness of their perception of her presence is set into an objective perspective on the next page, where the figures are seen in relation to each other, and we see how distant she still is; this perspective also tunes readers into a binary awareness of the very smallness (and everydayness) of the moment, which makes it all the more poignant. I think we could argue for another sort of epiphany here, when, as perhaps a 'second act,' the child reader shares and emotionally relates to not simply the world of the text, but the perspectives of the horizon fictively projected beyond it. Joyce's idea of adjusting the parts to a whole in 'exquisite' relationship may also be significant as part of the more technical nature of what Nodelman calls the 'highly specialised relationship' between the words and pictures of a text (Nodelman 1988, p.201). A text which deliberately plays with the process of adjusting parts to a whole, confounding assumptions, and subsequently overtly leading into a knowledge of its universal, is the wordless book, Zoom, by Istvan Banyai.

Inscape and the epiphany each contributes to my major concern of thisness, and in some instances the terms can be used interchangeably. There are also differences however; for my purposes thisness most accurately describes that intensity or saturation of artistic structure which, like saturation in art terms, 'manifests itself most powerfully in the analysis of the relations between connotations and perception.' (Wright and Rainwater, quoted in Nodelman 1988, p.66). I see inscape as more intrinsically semiotic: the innate essence of things when perceived signifies and becomes a sign of a deeper reality. Its emphasis is on acute observation and on the subsequent spiritual revelation of the perceiver. Inscape is not a transient endowment but is always there for the person who seeks it; it is what the pictures always make available to readers. The epiphany is more ephemeral; it is a transient endowment, a special moment as Hollindale describes, 'significant' and infused with what Joyce calls 'radiance.' It is more emotional; its 'radiance' is all-consuming as an intensely subjective encounter, a moment of insight for fictive characters. In simple terms, inscape tends to affect the reader in life-world; the epiphany tends to affect a character in fictive world: both are essentially subjective responses. On the other hand, while it can sometimes be similarly 'radiant,' the 
perception of thisness is a much more objective description of the sequence of picture after picture that tells a picture book story. Scholars have differed as to how they see the exact nature of haecceitaswhether it is a principle of indivisibility or a principle of distinction-but as a notion of formal distinction, common unity and difference it helps to formulate specific questions that we can askin relation to texts. What is it about the narrative form, or the artistic shape (verbally or visually expressed) of this textual moment which makes it distinctive and individuated despite or because of the inherent unity of all its components?

At the end of Anne of Green Gables, Anne sits at her bedroom window, as she has done countless nights before, and is filled with a sense of the 'alrightness' of the world. This is clearly an epiphanic moment; it is deeply significant in terms of both narrative and the representation of subjectivity. It is the resolution of the whole text: before coming to Green Gables, Anne has only, in Zipes' phrase, 'glimpsed the possibilities of home' (1979, p.154); now, from the security of her own'really truly home' (Montgomery $1983, p .22$ ) and all that it has brought her in terms of human relationships, her world has become 'alright' and she is home. 'Coming home' has reached its culmination in the last two pages of the text, as Anne walks from the graveyard back to Green Gables (pp.255-256). It is a moment of reconciliation not only with Gilbert but with death (Matthew's) and with life (her duty to Marilla), and as she sits at her window she is 'companioned with a glad content'. What distinguishes this night from all the similar others? Everything in narrative has come together in a perfect thisness. This moment accesses all those moments that have gone before and anticipates all those moments to come; it is both culmination and preview, convergence and divergence. In subjective perceptual terms Anne is focalising a sacramental moment of her inner world in an epiphany which is thematically characterised by both her acceptance of the present and her hope for the future; this is then translated into her perceptions of the outer world- the 'dear old world' in which she is 'glad to be alive.' However, if we pick up Stephens' definition of a 'conceptual' point of view comprising 'all acts of interpretation' (Stephens 1992b, p. 43), it can be seen that it is the reader, not Anne who, through Montgomery's art of verbally creating a concentrated and saturated textual thisness, is given the agency to read and interpret the scene in all its fullness and aesthetic form.

Another verbal moment which describes characters experiencing an epiphany as part of narrative, the artistic form of which can be described as thisness, is when Rat and Mole, maintaining watch for little Portly, come to what Rat calls the place of his 'songdream, the place the music played for me:'

On either side of them, as they glided onwards, the rich meadow grass seemed that morning of a freshness and a greenness unsurpassable. Never had they noticed the roses so vivid, the willow herb so riotous, the meadowsweet so odorous and pervading.

(Grahame 1980, p.105)

Thisness in verbal texts is arguably more likely to happen in the artistic representation of epiphanic moments in story world; the pictures of picture books, on the other hand, represent in the life-world of the child reader an artistic continuum of thisness, each one a combination of highly charged specifics of shape, outline, space, colour and visual relationship: Julie Vivas's illustrations of The Nativity, of the moment of meeting between the boy and the duck in I Went Walking, of the symbols of memory in Wilfrid Gordon McDonald Partridge; Donna Rawlins' picture of the woman and child sitting on the steps eating cake in Digging to China; Jane Dyer's representation of a series of ordinary but particular moments of mother/child relationships in Time for Bed; Craig Smith's explosion of characters in Where's Mum? Many pictures in picture books are artistic collocations of moments that are characterised in general by the underlying principle of haecceitaseach picture is a single frame representative of a whole sequence, but with its own special power, 
significance and integrity because of the specific composition of all of its parts. Their specialty is the representation not only of the fictive character's epiphanic moment that is part of narrative, and not only the closeup which is the revelation of inscape to the tuned-in reader; they always, through the very act of being selected as one moment of an implicit artistically shaped and selected continuum, express a deep particularity, a thisness. Their power is also intensified by what has not been illustrated, which in picture books not only operates as a gap but as a suspense or focus-concentrating and intensifying what appears in the illustrations.

Moreover, these textual attributes are amplified by expectations of how they will be received; this reflexively builds on and is built into verbal and visual text. The metafictional frame of Winnie-thePooh (a father telling a story to his son about his son's teddy bear) is a ready example of how audience itself frames the way a story is told. Writers and illustrator seek both to represent and to access the freshness of children's perception and their fluidity of thought and ideas. In other words, in their representation of the unique quality of moment they also seek to capture and portray the characteristics of the child's viewing eye. Hopkins wrote in his diary' I saw the inscape though freshly, as if my eye were still growing' (12 December 1872). The perspective of the child as implied reader of children's texts imbues its own special distinction: this is there for the child to see, this is how the child might see it. (A third element is of course the ideological issue of how we might want the child to see it-or not see it). In Eric Carle's text The Tiny Seed, a flower, simply drawn as a child might draw it, fills the page in a bright close up, visually bursting with its particularity, colour and vibrancy, its this-is-whatit-is-ness. Henry's Bed, a picture book by Margaret Perversiand Ron Brooks, exemplifies how the clever interaction between words and pictures transforms a simple dialogue into what Genette calls a 'web of structure and a cohesiveness of meaning' (quoted in Ricoeur 1985, p.181). Here a temporal and spatial sequence of precise, individuated moments, the 'being-in-the-world proposed by the text' opens up outer worlds and inner worlds, narrative and artistic, configuring into a thematic mesh of childhood fears, parental frustration, and the human fear of change and loneliness, the 'compound of insignificances' of everydayness which 'though it occupies and preoccupies...,is practically untellable' (Lefebvre 1971, p.24). These are brought together in a gentle resolution which is almost a metanarrative of the everyday cycle of life and growth and more implicitly of birth and death.

I want now to briefly consider several aspects of haecceitas appropriate to the discussion of children's books.

1 Thisness as visual metonymy/synecdoche It is helpful to conceptualise some texts not only in terms of semiotics, but also in terms of an haecceitas which operates as a type of visual metonymy or synecdoche. What is represented is not so much a sign as a representation of what the implied child sees in a close but limited focus. In Lone Morton's Teddy's Busy Day, the everyday activities of Teddy's day are repeatedly represented by one thing standing for the whole. Going to playgroup for example is represented by the car. The text 'Later he has a shower' is illustrated by a narrow-focus bathroom close-up-a full page of blue and white tiles with a bottle of shampoo, a shower nozzle and a soap holder with soap. The text 'and jumps into bed' is accompanied by the picture of a brightly striped bed which dominates the whole page. This is a very particular bed, the representation of which is more accurately described through an interpretative schemata based on thisness-particularity, individualising difference-than on semiotics. In Doonan's terms, it is denotation, but it also carries with it a load of what she refers to as exemplificalion (Doonan 1993, p.15): the abstract notions of cosiness and security. The bed is the object of the verbal text'and jumps into bed'-and the whole of the visual text, until the child as a deliberate act places the flap teddy in the picture. That should be the end of it- 
but it's not. 'The whole, then [that is, words and pictures] is more than the sum of its parts,' writes Nodelman (p. 200). What happens is that the particularising difference, that this is Teddy's bed, operates to inflate it with the immediate metonymic thisness upon which its semiotics depend. Stephens' comments about realistic fiction can meaningfully be applied here, as they could to the Montgomery passage discussed earlier: the meaning of the passage is whole within itself but 'also forms part of a larger, signifying structure' (Stephens 1992a, p.248).

2 Thisness as artistic representation of the single entity divorced from time, space and context

It is a common device in children's illustration to draw objects without a background.

In 'Quack!' Said the Billy-goat, by Charles Causley and Barbara Firth, the cat flies, the sow and her two piglets hover, in white space: this is an indication that it is the thisness of the animals that really matters. There is no context in this text-nospatial or temporal background--they are insignificant compared to the object. As Nodelman says:

[W]hile white space around a picture can act as a frame, create a sense of constraint, and demand detachment, it can also do just the opposite; it can provide a focus that demands our involvement. That happens when a picture ends at the edges of the objects it depicts; isolating characters against a white space the shape of their own bodies forces attention upon them.

(Nodelman 1988, p.53.)

Benson reverses this process in Owl Babies; here a similar effect is created, in a striking chiaroscuro, by isolating the white figures of the baby owls against the threatening darkness of background.

3 The thisness of place

This is a fascinating area of discussion which needs a paper of its own. Words and pictures create story world and its horizon, the virtual reality of being-inthe-text. Specificity of place is a significant characteristic of much children's literature.
Sometimes it is so specific that maps are included (Pooh Corner, the riverbank); in other books the place may be so individually described that keen readers can sit down and draw their own map (of Avonlea, for example). Place is of course more than the geography which is location; it includes as part of its thisness the temporal specific that is time and the wider containment that is culture: My Place, by Nadia Wheatley and Donna Rawlins, provides an obvious example. A part of place is also the subjective setting (internal and external) within which such description is received and perceived (again a telling example is My Place with its inclusivity and subjective heteroglossia). Perceptions of place therefore function, to slightly shift an idea of John Shotter, as 'extensions of ourselves' (Shotter 1993, p.35). When place is treated with such specificity, it can become metaphorically enlarged into'space' - place seen in relation to its perception, with denotative and connotative dimensions of, for example, intervals and gaps and distances that are not only spatial but temporal, not only syntagmatically geographic but historical. Anne's world is so specific that she must rename it, but her doing so is also a reflection of her own history. 'Place' expanding to 'space' is abstract and active, lending itself to metaphor; it extends the imaginative potential for thisness. As Bal notes, the Russian critic Jurij $M$. Lotman has pointed to the predominance of the dimension of space in the descriptive language of human imagination:

In support of his contention he lists a number of convincing examples of spatial terms we use to indicate abstract concepts, such as 'infinite' for an 'immeasurably' large quantity, 'distance' for a deficient relationship between people. Incidentally even the word 'relation' itself would seem to support Lotman's contention.

(Bal 1985, p.43)

Place opening up to 'space' becomes part of that 'internalisation of external processes' which, according to Turner, constructs the view of individual self which constitutes subjectivity (1986, p.88). 
4 Thisness as a means of art ordering everyday worlds

If, as Kermode states, ' we use art to stamp order on the everyday chaos of existence' (1966, p.46) then this gives an added significance to children's literature, likely to be the first expression of any sustained artistic form presented to most children. Its thisness gives images for children to make sense of their day by day activity (as Henry's Bed does) and gives another dimension to Joyce's idea of the 'incarnation' of 'artisticmeaning' living in the world's body. Merleau-Ponty writes:

The ontological world and body which we find at the core of the subject are not the world or body as idea, but on the one hand the world itself contracted into a comprehensive grasp, and on the other the body ilself as a knowing-body. (Merleau-Ponty, 1962, p. 408)

This is a particularly helpful way of looking at children's literature. Each child's book can be seen as its own particular artistic expression of a thisness of world, of one specific moment of its being 'contracted into a comprehensive grasp.' Children's books thus become a sort of cumulative critical hermeneutic, a methodology of interpretation, the conventions and artistic form of which children quickly learn to recognise. These highly concentrated ('contracted') verbal and pictorial representations offer connection and handholds, frequently through everydayness, onto larger and deeper teleological, epistemological and phenomenological issues. The Wolf is an example, as are John Brown Rose and the Midnight Cat and Anne of Green Gables; there are countless others. We can relate this concept to visual arts. Many of the pictures in picture books could well be described as genre paintings, that type of painting developed by the Dutch artists of the seventeenth century, who, resisting the tradition of religious subjects, focused instead on the everyday: women in genteel but ordinary middle class life carrying out their domestic routines. There is a great attention in genre painting to precise detail and also to light, as in Vermeer's depictions of sunlight falling through windows and doors. This detail and light illuminated more than the actual scene which it was depicting and these contracted worlds are telling of relationships and of lives lived beyond the actual painting (the world of Ricoeur's 'horizon'). Some of Tanner's illustrations in The Wolf resemble genre paintings; their light illumines subjective experiences set in the context of the intersubjective relationships of the everyday. In another way, representations of otherness/ marginality within a framework of the everyday, such as Rachel Isadora's At the Crossroads, make artistic connections through ordered moments of thisness that include in this text bath time and games. ${ }^{2}$ Texts representing other cultures are interesting for what they reveal about different artistic interpretative schemata-'new forms of being different' (Blei 1997, p.11); they also raise the vexed question of what constitutes authenticity, and how it is 'reflected through the logicality of art form' (Mo and Shen 1997, p.92).

5 Thisness as the resonation of subjectivity Picture books, in their representation of the collaborative social activity which Vygotsky conceives as fundamental to the development of individual personality, more than any other texts give face to the multiple identities that the members of their society exhibit. Such representations are of course ideologically encoded to fulfil societal agendas. The close focus of picture books artistically represents, as part of its narrative, dialogical and intersubjective encounters with others; it also provides multiple visual sites for the 'becomingness' which is very often a thematic concern. A recent example is Champions, by Jonathan Harlen and Emma Quay; the fact that the animal figures extend beyond the page is an artistic representation of growing and potential for growth. Sendak's illustrations in Outside Over There present the exact opposite-here the imaginative wildness of Ida is eventually thematically and pictorially contained and restrained 'by the power of words-in this case, loving words-to reflect ideologies and impose expectations of roles and behaviours;' Ida ends up like the flowers, 'pretty 
but tamed....and kept in their proper place behind the fence, which does not seem too far away from the arbor' (Johnston 1995, pp.215, 214).

\section{Thisness as social-cultural history}

I have argued elsewhere that, particularly in relation to haecceitas, the chronotopes (Bakhtin's term for narratological and ideological time-space relationships) of the picture book play a significant role as texts of sociocultural history: firstly, because of their sheer number and the distinctive and copious detail with which they overtly and covertly depict everydaylife; secondly, because of their concentrated and urgent focus; and thirdly, because of their carriage of prevailing ideologies, societal assumptions and attitudes Johnston 1997, pp. 7180 ). I would also argue that an appreciation focused on thisness and especially on the everydayness of the material in children's books is relevant to current discussions, by Peter Hunt and others, concerning the relationships between 'theory and history and the application of texts' (Hunt 1997, pp.201-202). The past is not merely 'history', although an 'historical' study may indeed focus on that aspect of it which is; 'theory' operates in a creative tension with 'the application of texts'; each is energised by the pull of the other. If we apply to the text the theoretical idea of implied child reader, the books of the past which continue to be read by today's children are books of the present, that happen to have been written in the past. There is a complex intertextuality of readership (which Hunt alludes to in his distinctions between 'children's children's books' and 'adults' children's books') in children's literature, related to the temporality that I referred to at the beginning of this paper. Like any intertextual relationship, this privileges both the past that is of the present, and the present. For instance, Perrault's Cinderella becomes more important when we note how much it has influenced other texts; it retrospectively inflatesfrom, say, twentieth century feminist readingsand gathers to a new 'meaning'. The gaps and the 'static' nature of the picture book make each illustration a moment of presentness that is not so much frozen as 'still': 'paused', 'poised', charged with thisness and highly specific and highly organised cultural schemata. As Nodelman points out, the techniques used to offer different sorts of information 'contribute so much to the telling of stories' (1988, p.157); they are also deeply-textured constructions and representations of human geography. The Ahlbergs' Peepo is a rich socio-cultural document, as are many of the books of Shirley Hughes. I noted earlier that any such document will be ideologically encoded; Nodelman makes the point very strongly in a recent paper that it is the construction of implied 'normalcy', as one aspect of the everyday in children's books, which is most revealing about social realities and cultural acceptabilities (1997, pp.118-125).

7 Thisness and the 'literacy of the imagination' In this age of multiple literacies, what I have called the literacy of the imagination (Johnston 1996, p.8) lies at the heart of the process and practice of literacy in all its forms. The load of ideological, cultural and personal meanings that co-exist in paradigmatic relations and reach out beyond words demands a critically literate imagination. 'In their very existence, then,' writes Nodelman, 'picture books express our assumption of the metaphorical relationships between appearance and meaning' (1988, p.49). Metaphor and metonymy are processes of the imagination, which the English children's writer, Peter Dickinson, has defined as 'the leap of the mind that places one perception alongside another and sees that somehow they fit...the sudden flash of thought...the imaginative leap' (Dickinson 1986, pp.43,51). The densely saturated words and pictures of children's books both give images-moments of concentrated thisness fraught with possibilities-to grow imaginations (shaping world) and deny images, thereby provoking imaginative stretch. Texts such as John Brown, Rose and the Midnight Cat resist an easy reading; their provocative polysemy and complex images are an example of the rich exposure that creates literate imaginations.

The idea of thisness is a productive means of looking at what happens in children's texts, both within 
narrative and as part of artistic structure. I have not sought here to describe the art of picture books in any specialised way; my focus is on a more philosophical approach. An appreciation of haecceitas helps us to consciously register, describe and engage with the elements of temporal and spatial concentration which are so much a part of children's books, and which situate readers (to use a term from film criticism to denote the superior place or vantage point for seeing) in a place of dominant specularity. It is thisness which achieves such positioning, not thatness nor even the related whatness (the quidditas of scholastic philosophy). The very specificity of thisness, its explicit close positioning, both spatially and temporally, to the 'here and now', helps to articulate children's literature as a literature of urgency.

Children's literature is a creative art. It is of course conceived creatively but it is just as importantly received by an audience which is itself in a continual state of flux and re-creation. The being-in-the-world that it proposes generates temporal and spatial propinquities which meet in creative thisness. In picture books the propinquity of words and pictures creates, in the mind-space, a 'blending' which rather than being merely the sum of the words and pictures, constitutes (creates) something more: a 'third space' (to borrow from cognitive science) that generates properties that can be found in neither of the 'input spaces' (Turner 1996, pp.5758). It is transdisciplinary, or should be; creatively telling and retelling its stories in many different voices and many different places. The philosophical concept of thisness helps us to understand, a little more, the multiplicity of what and how children's literature can mean.

Notes

1 I have discussed this concept in relation to the Anne books of L.M.Montgomery in 'Reaching Beyond the Word', Canadian Children's Literature (in press).

2 The perception of 'otherness' of course depends on where the reader is located

\section{References}

Ahlberg, J. and A.(1981) Peepo. London, Picture Puffin. Baillie, A. and J. Tanner (1988) Drac and the Gremlin. Melbourne, Viking Kestrel.

BaI, M. (1985) Narratology: Int roduction to the Theory of Narrative. Toronto, University of Toronto Press.

Bakhtin, M.M.(1981) The Dialogic Imagination. Austin, University of Austin Press.

Banyai, I. (1995) Zoom. New York, Viking.

Barbalet, M. and J.Tanner(1991) The Wolf.Melbourne, Penguin.

Blei, C. (1997) 'The country of corners: linguistic and pictorial portrayals of the familiar and the foreign,' Bookbird 35, 1, 6-11.

Booth, W. (1968) in Schutte, W. M. (ed) Twentielh Century Interpretations of 'A Portrait of the Artist as a Young Man'. New Jersey, Prentice-Hall.

Burningham, J. (1977) Come Away from the Water, Shirley. London, Cape.

Carle, Eric (1987) The Tiny Seed. London, Hamish Hamilton/Puffin.

Carroll, L. (1865) Alice's Adventures in Wonderland. London, Macmillan.

Causley, Charles and Barbara Firth (1997) 'Quack!' Said the Billy-goat. London, Walker Books.

Doonan, J. (1993) Looking at Pictures in Picture Books. Stroud, Glos., Thimble Press.

Featherstone, M. (1992) (ed) Cultural Theory and Cultural Change. London, Sage Publications.

Gardner, W. H. (1961) Poems and Prose of Gerard Manley Hopkins. Ringwood, Victoria, Penguin.

Gleeson, L. illust. Craig Smith (1997) Where's Mum? Sydney, Omnibus.

Grahame, K. (1980) The Wind in the Willows. London, Methuen.

Harlen, Jonathan and Emma Quay (1998) Champions. Milson's Point, Random House.

Hollindale, P. Signs of Childness in Children's Books. Stroud, Glos., Thimble Press.

Hunt, P. (1997) 'Passing on the past: the problem of books that are for children and that were for children', Children's Literature Association Quarterly $21,4,200-202$ 
Isadora, Rachel (1993) At the Crossroads. London, Red Fox.

Johnston, R, R. (1995) 'The special magic of the eighties: shaping words and shape-shifting words', Children's Literature in Education 26, 4. 211-217.

Johnston, R.R.(1996) ' Connecting and community: how to encourage your child to become a reader,' Real Books for Real Kids. Parramatta, Australian School Library Association pp.1-10.

Johnston, R.R. (1997) in Nimon, M. (ed) Old Neighbours, New Visions. Centre for Children's Literature, University of South Australia, pp.71-80.

Joyce, J. (1960) A Portrait of the Artist as a Young Man. Ringwood, Victoria, Penguin.

Lefebvre, H. (1971) Everyday Life in the Modern World. London, Penguin.

Kermode, F. (1966) The Sense of an Ending. New York, Oxford University Press.

Mo, W. and W. Shen (1997) 'Reexamining the issue of authenticity in picture books,'

Children's Literature in Education, 28, 2, 85-93.

Montgomery, L. M. (1983) Anne of Green Gables. Sydney, Angus and Robertson.

Morton, Lone (1997) Teddy's Busy Day. Ringwood, Victoria, Viking.

Nodelman, P. (1988) Words About Pictures. Athens, Georgia, University of Georgia Press.

Nodelman, P. (1997) 'Ordinary monstrosity: the world of Goosebumps.' Children's Literature Association Quarterly 27, 3, 118-125.

Perversi, M. and Ron Brooks (1997) Henry's Bed. Melboume, Viking.

Rawlins, D. (1988) Digging to China. Sydney, Ashton Scholastic.

Ricoeur, P. (1985) Time and Narrative. Chicago, University of Chicago Press.

Rimmon-Kenan (1983) Narrative Fiction: Contemporary Poetics. London, Methuen.

Sendak, M.(1981) Outside Over There. London, Bodley Head.

Sendak, M. (1967) Where the Wild Things Are.London, Bodley Head.
Shotter, J. (1993) Cultural Politics of Everyday Life. Buckingham, Open University Press.

Stephens, J.(1992a) Language and Ideology in Children's Fiction. London \& New York, Longman.

Stephens, J.(1992b) Reading the Signs. Kenthurst, Sydney, Kangaroo Press.

Turner, G. (1986) National Fictions. North Sydney, Allen \& Unwin.

Turner, M. (1996) The Literary Mind. New York, Oxford University Press.

Vivas, J. (1986) The Nativity. Adelaide, Omnibus.

Waddell, M. and P. Benson (1992) Owl Babies. London, Walker Books.

Wagner, J. and Ron Brooks (1977) John Brown, Rose and the Midnight Cat. London, Kestrel.

Zipes, J. (1979) Breaking the Magic Spell. London, Heinemann.

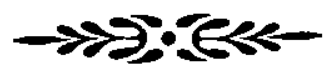

\section{Biographical Note}

Dr. Rosemary Johnston lectures at the University of Technology, Sydney. She is an Associate Secretary of the Bureau of the Federation Internationale des Langues et Literatures Modernes and Director of the Centre for Research and Eduction in the Arts at University of Technology Sydney. She is also Secretary of the International Research Society for Children's Literature (IRSCL).

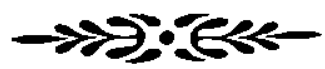

